\title{
Development of a clinical laboratory data base of hyper and hypo alpha lipoproteins in Campinas-SP and neighboring region
}

\author{
Construção de um banco de dados clínico laboratorial de hiper e \\ hipoalfalipoproteinêmicos em Campinas-SP e região
}

\begin{abstract}
Eliane Soler Parra ${ }^{1}$; Vanessa Helena de Souza Zago²; Natália Baratella Panzoldo ${ }^{3}$; Fernanda Alexandré; Felipe Vendrame;
Vitor Wilson de Moura Virginio5; Isabela Calanca Vieira ${ }^{4}$; Marcelo Scarpari Dutra Rodrigues ${ }^{6}$; Angela de Souza Cassol7; Fabio D’Alexandri ${ }^{8}$; Vera Sylvia Castanho $^{9}$; Rui Nakamura ${ }^{10}$; Jamal Baracat ${ }^{11}$; Mirian Regina Gardin Danelon ${ }^{12}$; Ronise Carla Sass Pozeti ${ }^{13}$; Ana Cândida Coutinho Facin ${ }^{12}$; Hilda Maria da Silva Honorio ${ }^{12}$; Simone de Cássia Dias Mesquita ${ }^{14} ;$ Marcio Jorge da Silva ${ }^{15}$; Marielza Crosgnac Feres Lot ${ }^{12}$; Valéria Sutti Nunes ${ }^{16}$; Camila Canteiro Leança ${ }^{17}$; Edna Regina Nakandakare ${ }^{18}$; Eder Carlos Rocha Quintã $0^{19}$; Eliana Cotta de Faria ${ }^{20}$
\end{abstract}

\begin{abstract}
Introduction: The development of research for diagnosis, prevention and treatment of atherosclerotic cardiovascular disease is of utmost importance due to the fact that it is the main cause of morbidity and mortality in Brazil. objective: To demonstrate the phases of the selection process for candidates with the aim to develop a clinical-laboratorial database of hyper alpha lipoproteinemic patients (hyper A) - high density lipoprotein cholesterol (HDL-C) $\geq 68 \mathrm{mg} / \mathrm{dl}$ ) and hypo alpha lipoproteinemic patients (hypo A) $-\mathrm{HDL}-\mathrm{C} \leq 39 \mathrm{mg} / \mathrm{dl}$. Material and methods: The volunteers were contacted after selection of lipid profiles from individuals treated at the Sistema Único de Saúde (SUS), Campinas-SP and neighboring area. Afterwards, the selected patients went through blood collection, clinical examinations and answered questionnaires on dietary frequency and physical activity. After this preliminary evaluation, some individuals were convened to another blood collection and, subsequently, were submitted to an ultrasonographic exam of the carotid arteries. Results: 0 nly $0.6 \%$ and $0.3 \%$ from 598,288 lipid profiles were selected for hyper $A$ and hypo A groups, respectively, including gender disparity. Lack of effective questionnaires $(75 \%)$, missing calls $(60 \%)$ and non-inclusion were the major hindrances in the construction of this database. Discussion: The difficulties to obtain eligible candidates were also due to the low prevalence of both groups hypo $\mathrm{A}$ and hyper A and the high prevalence of pathologies that contribute to non-genetic variations of HDL-C. Conclusion: In spite of the obstacles in the development of this database, this study brought about several scientific publications. Furthermore, the development of molecular analyzes and functionality will shortly generate other findings, contributing to the diagnosis and follow-up of HDL dyslipidemias.
\end{abstract}

Key words: health institutes; HDL-C; data collection.

First submission on 20/03/12; last submission on 26/11/12; accepted for publication on 21/12/12; published on 20/02/13

1. Currently a Doctorate's candidate in Clinical Medicine from Faculdade de Ciências Médicas da Universidade Estadual de Campinas (FCM-UNICAMP)

2. Master in Medical Science from FCM-UNICAMP.

3. Currently a Doctorate's candidate in Medical Science from FCM-UNICAMP.

4. Currently a Master's candidate in Clinical Medicine from FCM-UNICAMP.

5. Currently a Master's candidate in Clinical Medicine from FCM-UNICAMP.

6. Resident Physician from FCM-UNICAMP

7. Resident Physician from FCM-UNICAMP.

8. Post-doctorate in Biological Science from FCM-UNICAMP.

9. Doctorate in Medical Science from FCM-UNICAMP; doctor from the Pathology Division of UNICAMP Clinical Hospital.

10. Radiologist from UNICAMP Clinical Hospital.

11. Doctorate in Medical Science from FCM-UNICAMP.

12. Biologist from the Clinical Biochemistry Section of UNICAMP Clinical Hospital.

13. Pharmaceutical and supervisor of the Clinical Biochemistry Section of UNICAMP Clinical Hospital.

14. Laboratory technician from the Clinical Biochemistry Section of UNICAMP Clinical Hospital.

15. Laboratory assistant from the Clinical Biochemistry Section of UNICAMP Clinical Hospital.

16. Post-doctorate in Health Science from FCM-UNICAMP; researcher from Hospital das Clínicas da Universidade de São Paulo (HCUSP).

17. Doctorate in Science from Faculdade de Medicina da Universidade de São Paulo (FMUSP).

18. Professor from the Endocrinology Department of FMUSP; post-doctorate in Health Science from University College London.

19. Professor Emeritus of FMUSP.

20. Associated professor from the Clinical Pathology Department of FCM-UNICAMP; post-doctorate in Health Science from Institut Nationale de la Santé e de la Recherche

Médicale, Université Paris. 
Eliane Soler Parra; Vanessa Helena de Souza Zago; Natália Baratella Panzoldo; Fernanda Alexandre; Felipe Vendrame; Vitor Wilson de Moura Virginio; Isabela Calanca Vieira; Marcelo Scarpari Dutra Rodrigues; Angela de Souza Cassol; Fabio D’Alexandri; Vera Sylvia Castanho; Rui Nakamura; Jamal Baracat; Mirian Regina Gardin Danelon; Ronise Carla Sass Pozeti; Ana Cândida Coutinho Facin; Hilda Maria da Silva Honorio; Simone de Cássia Dias Mesquita; Marcio Jorge da Silva; Marielza Crosgnac Feres Lot; Valéria Sutti Nunes; Camila Canteiro Leança; Edna Regina Nakandakare; Eder Carlos Rocha Quintão; Eliana Cotta de Faria

\section{INTRODUCTION}

Circulatory system diseases (CSD) constitute the main death cause in Brazil $(31.25 \%)^{(15)}$. Due to its high prevalence and consequent impact on morbidity and mortality ${ }^{(23)}$, the development of multidisciplinary academic research in the diagnosis and prevention of CSD has become crucial.

Dyslipidemias represent a major risk factor in the development of atherosclerotic disease, the most important cause of cardiovascular morbidity ${ }^{(7)}$.

Owing to regional diversity and high ethnical heterogeneity ${ }^{(26)}$, the development of an updated database, which bears clinical and epidemiological relevance, constitute an invaluable tool for the follow-up of population and pathologies and a source of innovative clinical research.

This study comprises the phases and hindrances involved in the selection process of candidates with primary or genetic hypo alpha lipoproteinemia (hypo A) and hyper alpha lipoproteinemia (hyper A) and its use as a model for other clinical laboratory studies in Brazil.

\section{MATERIAL AND METHODS}

\section{Study outline}

The project "Relation between serum HDL cholesterol concentrations and cholesterol metabolism in human lymphomonocytes" from Fundação de Amparo à Pesquisa de São Paulo (FAPESP) no 06/60585-9 had as coordinator Dr. Eder C. R. Quintão, professor emeritus of Faculdade de Medicina da Universidade de São Paulo (FMUSP) and as researchers associated professor Dr. Eliana Cotta de Faria from Faculdade de Ciências Médicas da Universidade de Campinas (FCM-UNICAMP) and Dr. Professor Edna Nakandakare from FMUSP. It began in 2008 with the aim to assess the correlation between serum high density lipoprotein (HDL) and its fractions and body cholesterol. Moreover, the objective was to study HDL functionality, metabolism and genetic regulation as well as its effects on subclinical atherosclerosis and carotid intima-media thickness (CIMT).

Candidates' selection was carried out with patients from Sistema Único de Sáude (SUS) from Campinas-SP and Americana-SP. Lipid profiles (total cholesterol [TC], low density lipoprotein cholesterol [LDL-C], high density lipoprotein cholesterol [HDL-C] and triglycerides) from UNICAMP Clinical Hospital and health centers from the Health Secretary of both municipalities were assessed according to agreements signed in 2008 and 2010, respectively.

The first selection (selection 1- Figure 1) included patients from 20 to 75 years of age, both genders, fulfilling the following exam criteria: $\mathrm{LDL}$ and triglycerides $\leq 130$ and $150 \mathrm{mg} / \mathrm{dl}$, respectively (VI Brazilian Guidelines for Dyslipidemia and Atherosclerosis Prevention) ${ }^{(21)}$, HDL-C $\geq 68 \mathrm{mg} / \mathrm{dl}$ (hyper A individuals ) or $\leq 39 \mathrm{mg} / \mathrm{dl}$ (hypo A individuals).
These HDL-C cutoff values correspond to 10 and 90 percentiles obtained in a previous study conducted as part of Dalpino's doctorate research ${ }^{(2)}$, which comprised 1,700 asymptomatic individuals and was carried out at the Lipid Laboratory of UNICAMP School of Medicine.

After the first selection, patients were contacted by phone to answer standardized questionnaires on life style, medication in use and presence of pathologies. Accordingly, another selection phase was reached and its inclusion criteria (selection 2, Figure 1) were the following: absence of secondary pathologies, body mass index (BMI) $\leq 25 \mathrm{~kg} / \mathrm{m}^{2}$, non smokers, no alcohol abuse ${ }^{(19)}$ (Dietary Guidelines Advisory Committee, 2005), and no medication that may interfere in the cholesterol metabolism (statins, fibrates, nicotinic acid, bile salt chelating agents , contraceptives, hormonal replacement therapy and anticonvulsants).

The individuals that met selection 2 criteria were invited to take part in the research at UNICAMP Clinical Hospital (visit 1, Figure 1) for blood collection after a 12 hour-fastening period, clinical exam and questionnaires assessing physical activity (adapted from Baecke et al. $)^{(1)}$ and dietary frequency (adapted from Furlan-Viebig and Pastor-Valero) ${ }^{(5)}$.

The daily lipid, carbohydrate and energy consumptions were estimated through a dietary frequency questionnaire and the conversion of food into nutrients was performed by DietPro5i program (Universidade Federal de Viçosa-Brazil). The physical activity indexes were estimated through a questionnaire structured by comparison and self-analysis questions, consisting of 16 questions that include three indexes of habitual physical activities in the last 12 months: 1) occupational or labor physical activity index (LI); 2) free time physical exercise index (EI); and 3) free time and locomotion activity index (FTI).

Visit 1 was designed to confirm and complement data collected from questionnaires completed on the phone (data confirmation, Figure 1). Several volunteers did not correspond to the initial profile and were reclassified as normo alpha lipoprotein individuals (normo A) with HDL-C between 40 and $67 \mathrm{mg} / \mathrm{dl}$, in view of the variation margin of approximately $10 \%$ in serum HDL-C concentrations ${ }^{(21)}$ between the phone triage period and the exam results from visit 1.

The volunteers from this selection phase were invited to take part in a second visit (visit 2, Figure 1) for new blood collection after a 12-hour fastening period, post-heparin material collection (analysis of hepatic lipase activity, lipase lipoprotein and endothelial lipase) and separation of lymphomononuclear cells (Becton Dickinson [BD] Vacutainer $^{\circledR}$ - cell preparation tubes). Afterwards, volunteers were invited to join in a third visit (visit 3, Figure 1) for carotid artery ultrasonography at the Radiology Department of UNICAMP Clinical Hospital in order to verify CIMT and the presence of carotid plaque as evaluation of subclinical atherosclerotic disease.

This project was approved by the Research Ethics Committee of UNICAMP School of Medicine under $n^{0} 120 / 2007$ and all participants signed a free informed consent. 


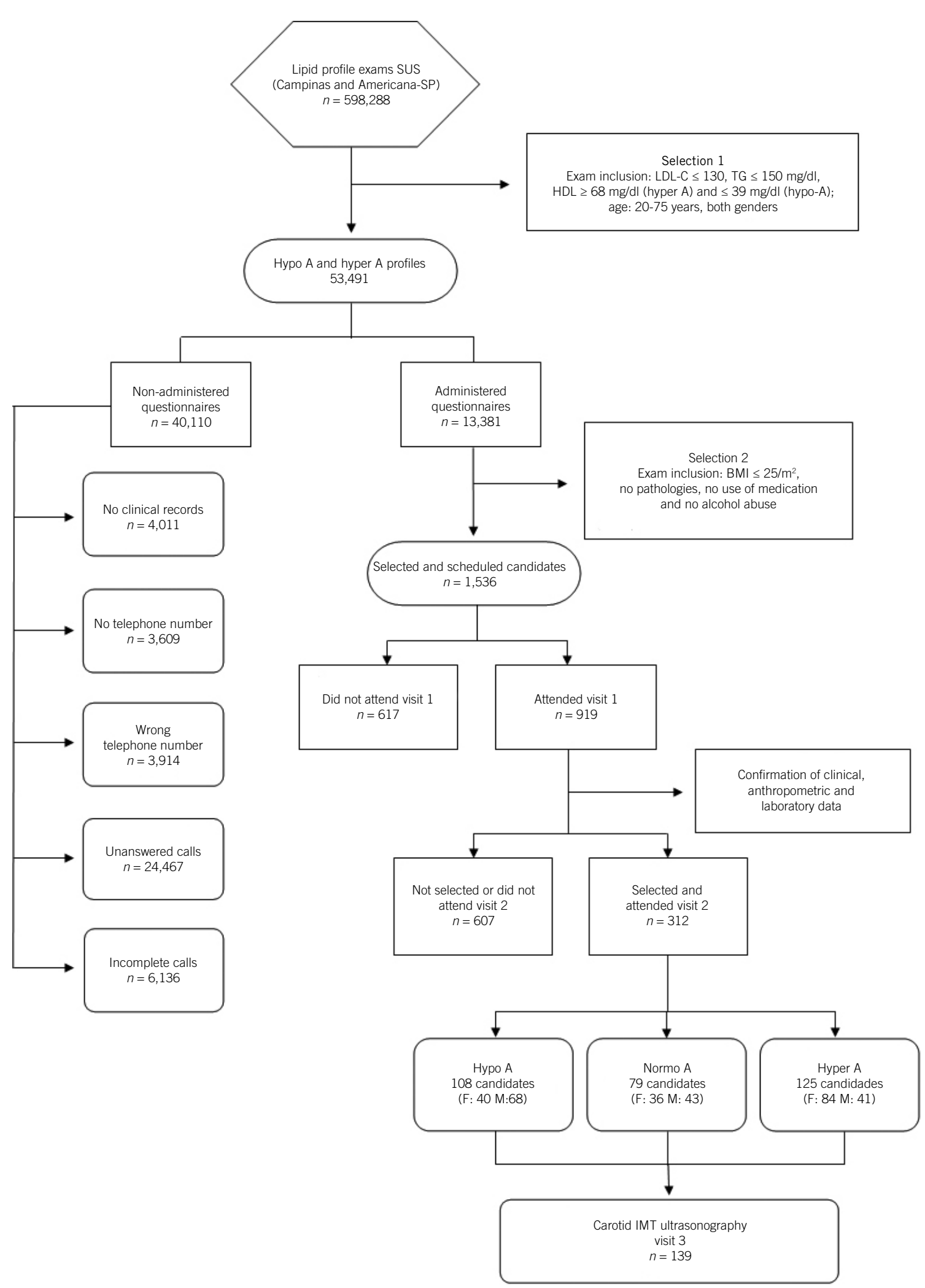

FIGURE - Quantification of candidates' selection process

SUS: Sistema Único de Saúde; LDL-C: low density lipoprotein cholesterol; TG: triglycerides; HDL-C: bigh density lipoprotein cholesterol; BMI: body mass index; F: female; M: male; IMT: intima-media thickness. 
Eliane Soler Parra; Vanessa Helena de Souza Zago; Natália Baratella Panzoldo; Fernanda Alexandre; Felipe Vendrame; Vitor Wilson de Moura Virginio; Isabela Calanca Vieira; Marcelo Scarpari Dutra Rodrigues; Angela de Souza Cassol; Fabio D’Alexandri; Vera Sylvia Castanho; Rui Nakamura; Jamal Baracat; Mirian Regina Gardin Danelon; Ronise Carla Sass Pozeti; Ana Cândida Coutinho Facin; Hilda Maria da Silva Honorio; Simone de Cássia Dias Mesquita; Marcio Jorge da Silva; Marielza Crosgnac Feres Lot; Valéria Sutti Nunes; Camila Canteiro Leança; Edna Regina Nakandakare; Eder Carlos Rocha Quintão; Eliana Cotta de Faria

\section{LABORATORY ANALYSES}

The analyses of uric acid, alanine aminotransferase (ALAT), aspartate aminotransferase (ASAT), gamma glutamyl transferase, urea, glucose, total cholesterol (TC) and serum triglycerides were performed by conventional Roche colorimetric enzymatic methods in automated BM Hitachi 917/Roche equipment. The very low density lipoprotein cholesterol (VLDL-C) was estimated as a fifth part of triglyceridemia and LDL-C was calculated by Friedewald equation for triglyceridemia levels up to $400 \mathrm{mg} / \mathrm{dl}^{(6)}$. Values above $400 \mathrm{mg} / \mathrm{dl}$ were calculated by direct homogeneous method (Roche).

HDL-C was measured through direct method (Sugiuchi et al. (22) $^{(2)}$ by use of Roche commercial kit.

Thyroid stimulant hormone (TSH) and free thyroxine (free T4) were measured by electrochemiluminescence with Elecsys 2010/ Roche equipment.

Apolipoprotein B100, Apo A-I and lipoprotein (a) (Lp(a)) were determined by nephelometry with BNII equipment and DadeBoehringer $^{\circledR}$ reagents.

Insulinemia was assessed by ELISA with (Millipore) kit.

\section{STATISTICAL ANALYSES}

Kruskal-wallis test was applied for comparison of variables, followed by Mnn-Whitney and Bonferroni post-test for multiple comparisons. The comparison of categorical variables was carried out through Chi-square test. The covariance test (ANCOVA) was applied for variable correction. The statistical analyses were conducted with SPSS 11.5 program for Windows. The adopted significance level was $5 \%(p \leq 0.05)$.

\section{RESULTS}

Figure 1 quantifies the results from 2008 to December 2011 and the phases involved in the selection process.

Approximately $67 \%$ of all lipid profiles (both genders) from the Health Secretaries were normo A, 22\% were hypo A and 11\% were hyper A. After the first selection, only 0.6 of hyper A and $0.3 \%$ of hypo A were selected for visit 2 with gender disparity.

There were at least 24 persons involved in the process, including regular undergraduate, junior undergraduate, post-graduate students, students from technical improvement programs as well as UNICAMP and USP staff.

The results of the appliance of this model in the population sample are presented in the anthropometric and biochemical characterization of candidates that took part in visit 2 (Tables 1 and 2). The significant differences among the three groups in several characteristics are highlighted in bold types. ANCOVA statistical adjustments were made for differences in confounding variables such as gender, age and BMI.

\section{DISCUSSION}

The difficulty in obtaining primary hyper A and hypo A individuals in the studied populations was one of the crucial points in this research protocol. Initially, we were not able to contact $75 \%$ of hyper A and hypo A individuals by phone, who had been chosen after selection 1. The main cause was unanswered phone calls, corresponding to approximately $60 \%$ of non applied questionnaires.

In face of this problem, we decided to contact them in alternative schedules, off- hours and even bank holidays. There were no scheduled appointments due to the fact that some candidates did not meet the inclusion criteria or were unavailable.

Approximately $88 \%$ of the individuals that filled in the questionnaire (selection 2) did not meet the inclusion criteria. Hence we were not able to make up for this loss.

After confirmation and complementation of data from the phone questionnaire (visit 1), only 33.9\% of candidates were selected and came to visit 2 . The inclusion criteria were not met because of the lack of information or misinformation during the first call, which led to the invitation of individuals that did not fulfill the criteria established for selection 2 .

The increase in triglycerides (> $150 \mathrm{mg} / \mathrm{dl}$ ) and LDL-C $(>130 \mathrm{mg} / \mathrm{dl}$ ) or other exam results was also a decisive factor that contributed to the exclusion of some volunteers.

By the end of the selection, the volunteers that came to visit 2 were sorted out into hyper A, hypo A and normo A groups, which presented disparity in gender frequency. There was a significant number of women in hyper $A$ whereas there was a higher number of men in hypo A. These characteristics are typical in the population ${ }^{(3)}$ and may be explained by the estrogen activity on HDL metabolism among women ${ }^{(24)}$. We attempted to correct this trend in hyper A group by reducing the number of selected women.

It was also complicated to obtain primary male hyper A individuals due to alcohol abuse verified on the questionnaire. Alcohol is the secondary cause of hyper $\mathrm{A}^{(10)}$. The high exclusion rates in our protocol may also be accounted for the fact that we were working with patients from SUS with high prevalence of pathologies and environmental risk factors for ACD (obesity, smoking, sedentary lifestyle, alcohol consumption and dietary habits), which ultimately lead to secondary variations in HDL-C.

In this study it is particularly worth mentioning that there was twice the number of lipid profile exam requests in hypo A group in comparison with hyper A group. Thus this may be due to the growing number of cases with secondary causes of hypo A such as metabolic syndrome ${ }^{(20)}$, diabetes mellitus, obesity ${ }^{(1)}$ and other causes in our population $^{(17)}$.

Although cases of metabolic syndrome were excluded, BMI and insulin levels were significantly higher in hypo A group, which suggests higher resistance to insulin ${ }^{(11)}$ as a secondary cause. However, BMI was within recommended values for normal weight $\left(<25 \mathrm{~kg} / \mathrm{m}^{2}\right)$.

The analysis of nutritional components conducted through the questionnaires demonstrated the similarity within the groups, which may indicate that these individuals were not secondary owing to the causes above. 
TABLE 1 - Clinical data on candidates' physical activity and dietary frequency (visit 2)

\begin{tabular}{|c|c|c|c|c|c|}
\hline & \multirow{3}{*}{$\begin{array}{c}\text { Hypo A } \\
(45-108)\end{array}$} & \multirow{3}{*}{$\begin{array}{c}\text { Hyper A } \\
(82-125) \\
M \pm S D\end{array}$} & \multirow{3}{*}{$\begin{array}{c}\text { Normo A } \\
(49-49) \\
\mathrm{M} \pm \mathrm{SD}\end{array}$} & \multicolumn{2}{|c|}{$p$ values } \\
\hline & & & & \multirow{2}{*}{$*$} & \multirow{2}{*}{$* *$} \\
\hline & & & & & \\
\hline Gender (F/M) & $40 / 68$ & $84 / 41$ & $36 / 43$ & $\leq 0.001^{\mathrm{a}, \mathrm{b}}$ & NS \\
\hline Age (years) & $39 \pm 14$ & $46 \pm 13$ & $43 \pm 13$ & $\leq 0.001^{\mathrm{a}}$ & NS \\
\hline Weight (kg) & $68.1 \pm 9.4$ & $59.8 \pm 8.9$ & $63.3 \pm 8.8$ & $\leq 0.006^{a, b, c}$ & NS \\
\hline Height (m) & $1.67 \pm 0.09$ & $1.62 \pm 0.08$ & $1.67 \pm 0.09$ & $\leq 0.001^{\mathrm{a}, \mathrm{b}}$ & NS \\
\hline BMI $\left(\mathrm{kg} / \mathrm{m}^{2}\right)$ & $24.3 \pm 2.5$ & $22.7 \pm 2.7$ & $22.6 \pm 2.4$ & $\leq 0.001^{\mathrm{a}, \mathrm{c}}$ & NS \\
\hline WC (cm) & $79.2 \pm 10$ & $72.2 \pm 7,9$ & $75 \pm 9.1$ & $\leq 0.004^{\mathrm{a}, \mathrm{b}, \mathrm{c}}$ & NS \\
\hline Hip (cm) & $95 \pm 7.4$ & $91.1 \pm 9.1$ & $91.5 \pm 9.3$ & $\leq 0.004^{\mathrm{a}, \mathrm{c}}$ & NS \\
\hline SBP (mmHg) & $119 \pm 12$ & $120 \pm 15$ & $121 \pm 15$ & NS & NS \\
\hline DBP (mmHg) & $79 \pm 9$ & $79 \pm 10$ & $79 \pm 10$ & NS & NS \\
\hline cIMT R (mm) & $0.68 \pm 0.25$ & $0.67 \pm 0.22$ & $0.74 \pm 0.36$ & NS & NS \\
\hline cIMT L (mm) & $0.68 \pm 0.26$ & $0.68 \pm 0.22$ & $0.72 \pm 0.38$ & NS & NS \\
\hline cIMT M (mm) & $0.68 \pm 0.24$ & $0.67 \pm 0.22$ & $0.73 \pm 0.33$ & NS & NS \\
\hline OI & $2.91 \pm 0.70$ & $2.81 \pm 2.81$ & $2.67 \pm 0.61$ & 0.031 & NS \\
\hline SI & $2.13 \pm 0.85$ & $2.31 \pm 0.78$ & $2.40 \pm 0.93$ & 0.060 & $0.007^{\mathrm{a}}$ \\
\hline FTAI & $2.59 \pm 0.81$ & $2.63 \pm 0.79$ & $2.58 \pm 0.71$ & NS & NS \\
\hline$\omega 6(\mathrm{~g})$ & $1.17 \pm 2.46$ & $0.69 \pm 1.85$ & $1.04 \pm 2.36$ & NS & NS \\
\hline$\omega 3(\mathrm{~g})$ & $0.58 \pm 1.47$ & $2.99 \pm 28.27$ & $0.38 \pm 1.17$ & NS & NS \\
\hline MFA (g) & $31.18 \pm 45.59$ & $27 \pm 45.47$ & $42.83 \pm 200.55$ & NS & NS \\
\hline PFA (g) & $15.16 \pm 7.92$ & $14.42 \pm 7.25$ & $13.16 \pm 6.78$ & NS & NS \\
\hline SFA (g) & $18.18 \pm 10.08$ & $17.14 \pm 11.27$ & $15.61 \pm 9.54$ & NS & NS \\
\hline Cholesterol (mg) & $279 \pm 146$ & $301 \pm 263$ & $266 \pm 186$ & NS & NS \\
\hline Phytosterols (mg) & $47.81 \pm 33.72$ & $67.70 \pm 168.68$ & $44.11 \pm 26.72$ & NS & NS \\
\hline Lipids (g) & $163 \pm 334$ & $185 \pm 385$ & $139 \pm 292$ & NS & NS \\
\hline Energy (kcal) & $2129 \pm 2393$ & $1787 \pm 877$ & $1878 \pm 792$ & NS & NS \\
\hline Carbohydrate (g) & $319 \pm 610$ & $265 \pm 202$ & $264 \pm 177$ & NS & NS \\
\hline
\end{tabular}

Values expressed as mean \pm standard deviation (minimum sample number-maximum sample number)

* p value referring to Kruskal-Wallis test followed by Bonferroni post-test; ** p value referring to ANCOVA test (corrections for gender, BMI and age) for comparison of variables among the three groups. $a$ : hypo $A \neq$ byper $A ; b$ : normo A $\neq$ hyper A; $c$ : normo $A \neq$ bypo A, statistically significant when $\leq 0.05$. Hypo A: bypo alpha lipoproteinemic; hyper A: hyper alph lipoproteinemic; normo A: normo alpha lipoproteinemic; M: mean; SD: standard deviation; F: female; M: male; BMI: body mass index; WC: waist circumference; SBP: systolic blood pressure; DBP: diastolic blood pressure; cIMT: carotid intima media thickness; R: right; L: left; M: middle of cIMT R and L; OI: occupational index; SI: sport index; FTAI: free time activity index; $\omega 6$ : omega 6 fatty acid; $\omega 3$ : omega 3 fatty acid; MFA: monounsaturated fatty acid; PFA: polyunsaturated fatty acid; SFA: saturated fatty acid; ANCOVA: covariance analysis.

The physical activity analyses revealed that sport activity rates were significantly higher in hyper A group in comparison with hypo A, even when gender, age and BMI were corrected, indicating a secondary modeling in HDL-C levels ${ }^{(13)}$.

Apart from all the hindrances encountered during the selection process of healthy candidates, which are commonly found in clinical research, our study outline with primary hyper A and hypo A individuals became more challenging due to the low prevalence of these HDL-C phenotypes ${ }^{(1,16,25)}$.

We proceeded to contact, select and recruit volunteers focusing on hypo A women and hyper A men as an attempt to increase the number of more extreme HDL-C cases. Currently, our value ranges for total population are 18 and $216 \mathrm{mg} / \mathrm{dl}$. We also established new cut-off values: HDL-C $<32 \mathrm{mg} / \mathrm{dl}$ for women and HDL-C $>82 \mathrm{mg} / \mathrm{dl}$ for men.

The study will include the following special serum exams in progress:

- HDL particle diameter by Laser Light Scattering (Nanotrac) ${ }^{(14)}$;

- determination of $\mathrm{C}$ reactive protein by immunoturbidimetry (Roche) $)^{(4,18)}$;

- analysis of paraoxonase activity ${ }^{(9)}$ with Paraoxon as substrate;

- hepatic lipase and lipoprotein lipase activities are assessed by the release of fatty acids from tritiated triolein emulsion; 
Eliane Soler Parra; Vanessa Helena de Souza Zago; Natália Baratella Panzoldo; Fernanda Alexandre; Felipe Vendrame; Vitor Wilson de Moura Virginio; Isabela Calanca Vieira; Marcelo Scarpari Dutra Rodrigues; Angela de Souza Cassol; Fabio D’Alexandri; Vera Sylvia Castanho; Rui Nakamura; Jamal Baracat; Mirian Regina Gardin Danelon; Ronise Carla Sass Pozeti; Ana Cândida Coutinho Facin; Hilda Maria da Silva Honorio; Simone de Cássia Dias Mesquita; Marcio Jorge da Silva; Marielza Crosgnac Feres Lot; Valéria Sutti Nunes; Camila Canteiro Leança; Edna Regina Nakandakare; Eder Carlos Rocha Quintão; Eliana Cotta de Faria

TABLE 2 - Candidates' clinical data (visit 2)

\begin{tabular}{|c|c|c|c|c|c|}
\hline & \multirow{3}{*}{$\begin{array}{c}\begin{array}{c}\text { Hypo A } \\
(45-108)\end{array} \\
M \pm S D\end{array}$} & \multirow{3}{*}{$\begin{array}{c}\text { Hyper A } \\
(87-125) \\
\mathrm{M} \pm \mathrm{SD} \\
\end{array}$} & \multirow{3}{*}{$\begin{array}{c}\text { Normo A } \\
(67-79) \\
\mathrm{M} \pm \mathrm{SD}\end{array}$} & \multicolumn{2}{|c|}{$p$ values } \\
\hline & & & & \multirow{2}{*}{$*$} & \multirow{2}{*}{$* *$} \\
\hline & & & & & \\
\hline HDL-C (mg/dl) & $34 \pm 5$ & $79 \pm 10$ & $52 \pm 9$ & - & - \\
\hline Cholesterol (mg/dl) & $154 \pm 23$ & $192 \pm 26$ & $167 \pm 24$ & $\leq 0.001^{\mathrm{a}, \mathrm{b}, \mathrm{c}}$ & $\leq 0.001^{\mathrm{a}, \mathrm{b}}$ \\
\hline Triglycerides (mg/dl) & $97 \pm 34$ & $66 \pm 25$ & $77 \pm 27$ & $\leq 0.009^{\mathrm{a}, \mathrm{b}, \mathrm{c}}$ & $\leq 0.001^{\mathrm{a}, \mathrm{c}}$ \\
\hline LDL-C (mg/dL) & $101 \pm 21$ & $100 \pm 21$ & $99 \pm 21$ & - & - \\
\hline VLDL-C (mg/dl) & $20 \pm 7$ & $13 \pm 5$ & $16 \pm 5$ & $\leq 0.006^{a, b, c}$ & $\leq 0.001^{\mathrm{a}, \mathrm{c}}$ \\
\hline LDL (LDL-C/Apo B) & 1.200 .12 & 1.270 .17 & 1.200 .14 & $\leq 0.009^{\mathrm{b}}$ & $0.009^{\mathrm{b}}$ \\
\hline Urea (mg/dl) & $29 \pm 8$ & $31 \pm 8$ & $31 \pm 9$ & - & - \\
\hline Glucose (mg/dl) & $84 \pm 11$ & $83 \pm 7$ & $85 \pm 9$ & - & - \\
\hline $\operatorname{ALT}(\mathrm{U} / \mathrm{l})$ & $21 \pm 13$ & $17 \pm 8$ & $20 \pm 10$ & $\leq 0.009^{\mathrm{a}}$ & - \\
\hline $\operatorname{ALP}(\mathrm{U} / \mathrm{l})$ & $65 \pm 15$ & $66 \pm 23$ & $63 \pm 18$ & - & - \\
\hline AST (U/l) & $20 \pm 7$ & $20 \pm 8$ & $21 \pm 7$ & - & - \\
\hline GGT (U/l) & $22 \pm 14$ & $22 \pm 16$ & $22 \pm 12$ & - & - \\
\hline TSH $(\mu \mathrm{UI} / \mathrm{ml})$ & $2.25 \pm 1.19$ & $2.27 \pm 1.28$ & $2.38 \pm 1.39$ & - & - \\
\hline FT4 (ng/dl) & $1.30 \pm 0.39$ & $1.28 \pm 0.18$ & $1.26 \pm 0.21$ & - & - \\
\hline Creatinine $(\mathrm{mg} / \mathrm{dl})$ & $0.83 \pm 0.17$ & $0.77 \pm 0.16$ & $0.83 \pm 0.18$ & $\leq 0.051^{\mathrm{a}, \mathrm{b}}$ & - \\
\hline Uric acid (mg/dl) & $4.94 \pm 1.24$ & $4.27 \pm 1.03$ & $4.71 \pm 1.15$ & $\leq 0.03^{\mathrm{a}, \mathrm{c}}$ & - \\
\hline Apo A-I (mg/dl) & $115 \pm 15$ & $194 \pm 24$ & $147 \pm 17$ & $\leq 0.001^{\mathrm{a}, \mathrm{b}, \mathrm{c}}$ & $\leq 0.001^{\mathrm{a}, \mathrm{b}, \mathrm{c}}$ \\
\hline Apo B (mg/dl) & $83 \pm 18$ & $80 \pm 16$ & $82 \pm 17$ & - & - \\
\hline $\mathrm{Lp}(\mathrm{a})(\mathrm{mg} / \mathrm{dl})$ & $18 \pm 17$ & $20 \pm 21$ & $21 \pm 24$ & - & - \\
\hline Insulin (uU/ml) & $6.85 \pm 3.93$ & $4.24 \pm 1.75$ & $4.22 \pm 2.50$ & $\leq 0.001^{\mathrm{a}, \mathrm{c}}$ & $0,001^{a, c}$ \\
\hline
\end{tabular}

Values expressed as mean \pm standard deviation (minimum sample number - maximum sample number)

* $\mathrm{p}$ value referring to Kruskal-Wallis test followed by Bonferroni post-test; *** $\mathrm{p}$ value referring to ANCOVA test (corrections for gender, BMI and age) for comparison of variables among the three groups. a: hypo $A \neq$ hyper $A ; b$ : normo $A \neq$ hyper $A ; c$ : normo $A \neq$ hypo A, statistically significant when $\leq 0.05$.

Hypo A: hypo alpha lipoproteinemic; hyper A: hyper alpha lipoproteinemic; normo A: normo alpha lipoproteinemic; M: mean; SD: standard deviation; HDL-C: high density lipoprotein cholesterol; LDL-C: low density lipoprotein cholesterol; VLDL-C: very low density lipoprotein cholesterol; LDL: low density lipoprotein (LDL size - LDL size value estimated by LDL/Apo B ratio); Apo B: apolipoprotein B; ALT: alanine aminotransferase; ALP: alkaline phosphatase; AST: aspartate aminotransferase; GGT: gamma glutamyl transferase; TSH: thyroid stimulant hormone; FT4: free thyroxine index; Apo A-I: apolipoprotein A-I; LP(a): lipoprotein a; ANCOVA: covariance analysis.

- cholesterol ester transfer protein (CETP) activity and phospholipid transfer protein (PLTP) by exogenous radiometric assays;

- genotyping of lymphomonocitary deoxyribonucleic acid for 32 polymorphisms of one nucleotide (SNP) in 22 genes (CETP, LH, LE, LPL, PLTP, LCAT, Apo A-I, Apo A-5, Apo C-3, Apo E, PAF-AH, P0N1, SR-B1, ABCA1, ABCG1, ABCG5, ABCG8, proteins associated with angiopoietin 4, cyclooxygenase 2, arachidonate 15-lipoxygenase, fatty acid desaturase 1 and oxidized 1 LDL receptor) directly involved in HDL metabolism and atherosclerotic disease that have been processed by OpenArray ${ }^{\circledR}$ from Applied Biosystems, which is located at the Medical Genetics Laboratory of FCM-UNICAMP (Fapesp project 2009/54114-1).

\section{CONCLUSION}

Despite the hindrances in the selection process and long period required for the development of this study database, we have yielded major results, culminating in 20 published articles, 6 submitted to publishing and 10 in current preparation. These publications have considerably enhanced the knowledge of HDL dyslipidemias.

Furthermore, this study aroused an additional concern as to public health, which consists of the fact that the search for a health center occurs once the established disease is present, demonstrating no preventive routine measures.

Therefore, we conclude this model may be applied in the construction of other database projects involving clinical research.

\section{ACKNOWLEDGMENTS}

To the volunteers, professors, students and staff from the accredited institutions and everyone from this team who has contributed to this study.

\section{RESEARCH SUPPORT}

Fapesp 2006/60585-9. 


\section{RESUMO}

Introdução: O desenvolvimento de pesquisa para diagnóstico e prevenção da doença aterosclerótica cardiovascular no Brasil é de grande importância por esta ser a principal causa de morbimortalidade no país. Objetivo: Demonstrar as etapas do processo de seleção de voluntários para a construção de um banco de dados clínico-laboratorial de indivíduos biperalfalipoproteinêmicos (biper A) colesterol da lipoproteina de alta densidade (HDL-C) $\geq 68 \mathrm{mg} / \mathrm{dl}$ - e hipoalfalipoproteinêmicos (hipo A) - HDL-C $\leq 39 \mathrm{mg} /$ dl. Material e métodos: Os voluntários são contatados a partir de resultados de perfis lipídicos de indivíduos atendidos pelo Sistema Único de Saúde (SUS) de Campinas-SP e região e, se selecionados, são convidados para coleta de sangue, exames clínicos e responder a questionários de atividade física e de frequência alimentar. Após essa avaliação, os indivíduos podem ser convocados para nova coleta de sangue e, posteriormente, para a ultrassonografia de carótidas. Resultados: Entre 598.288 perfis lipidicos recebidos das redes públicas, apenas 0,6\% e 0,3\% compuseram os nossos grupos hiper A e bipo A, com disparidade entre os gêneros. A falta de questionários efetivos (75\%), das chamadas não atendidas (60\%) e a não inclusão foram os pontos mais difíceis na construção do banco de dados. Discussão: A dificuldade de obtenção de voluntários elegiveis também se deve à baixa prevalência de hipo A e hiper A è alta prevalência de patologias que contribuem para variações não genéticas do HDL-C. Conclusão: Apesar das dificuldades na criação da base de dados, este estudo gerou várias publicações e, com o desenvolvimento das análises moleculares e da funcionalidade, muitas outras seguirão em curto periodo, fatos contribuintes para o diagnóstico e o acompanbamento das dislipidemias envolvendo a HDL.

Unitermos: instituições de saúde; HDL-C; coleta de dados.

\section{REFERENCES}

1. CEFALU, A. B. et al. Novel mutations of CETP gene in Italian subjects with yperalphalipoproteinemia. Atherosclerosis, v. 204, n. 1, p. 202-7, 2009.

2. DALPINO, F. B. Caracterização e ritmos biológicos de parâmetros bioquímicos séricos em uma população brasileira. Campinas, 2005. Tese (Doutorado) - Faculdade de Ciências Médicas. Universidade Estadual de Campinas. 2005.

3. DALPINO, F. B.; SODRE, F. L.; DE FARIA, E. C. The use of a hospital laboratory cohort to estimate the prevalence of dyslipidemia in an adult Brazilian population. Clin Chim Acta, v. 367, n. 1-2, p. 189-91, 2006.

4. EDA, S. et al. Development of a new microparticle-enhanced turbidimetric assay for C-reactive protein with superior features in analytical sensitivity and dynamic range. J Clin Lab Anal, v. 12, n. 3, p. 137-44, 1998.

5. EHNHOLM, C.; KUUSI, T. Preparation, characterization, and measurement of hepatic lipase. Methods Enzymol, v. 129, p. 716-38, 1986.

6. FRIEDEWALD, W. T.; LEVY, R. I.; FREDRICKSON, D. S. Estimation of the concentration of low-density lipoprotein cholesterol in plasma, without use of the preparative ultracentrifuge. Clin Chem, v. 18, n. 6, p. 499-502, 1972.

7. HACKAM, D. G.; ANAND, S. S. Emerging risk factors for atherosclerotic vascular disease: a critical review of the evidence. JAMA, v. 290, n. 7, p. 932 40,2003 .

8. JaUHiainen, M.; EHNHOLM, C. Determination of human plasma phospholipid transfer protein mass and activity. Methods, v. 36, n. 2, p. 97101, 2005 .

9. KLEEMOLA, P. et al. Dietary determinants of serum paraoxonase activity in healthy humans. Atherosclerosis, v. 160, n. 2, p. 425-32, 2002.

10. KONTUSH, A.; CHAPMAN, M. J. Lifestyle modifications, in high-density lipoproteins: structure, metabolism, function, and therapeutics. John Wiley \& Sons, Inc.: Hoboken, NJ, USA, 2011.
11. KONTUSH, A.; CHAPMAN, M. J. Abnormal metabolism, in high-density lipoproteins: structure, metabolism, function, and therapeutics. John Wiley \& Sons, Inc.: Hoboken, NJ, USA, 2011.

12. LAGROST, L. Determination of the mass concentration and the activity of the plasma cholesteryl ester transfer protein (CETP). Methods Mol Biol, v. 110, p. 231-41, 1998

13. LEON, A. S.; SANCHEZ, O. A. Response of blood lipids to exercise training alone or combined with dietary intervention. Med Sci Sports Exerc, v. 33, Suppl. 6, p. S502-15; discussion S528-9, 2001.

14. LIMA, E. S.; MARANHAO, R. C. Rapid, simple laser-light-scattering method for HDL particle sizing in whole plasma. Clin Chem, v. 50, n. 6, p. 1086-8, 2004.

15. Ministério da Saúde. Datasus: informações de saúde. Disponível em: $<$ http:/tabnet.datasus.gov.br/cgi/tabcgi.exe?idb2010/c04.def>. Acesso em: 26 fev. 2012

16. OKA, T. et al. Distribution of human plasma PLTP mass and activity in hypo- and hyperalphalipoproteinemia. J Lipid Res, v. 43, n. 8, p. 1236-43, 2002.

17. PEREIRA, P. B. et al. Lipid profile of schoolchildren from Recife, PE. Arq Bras Cardiol, v. 95, n. 5, p. 606-13, 2010.

18. PRICE, C. P. et al. Development and validation of a particle-enhanced turbidimetric immunoassay for C-reactive protein. J Immunol Methods, v. 99, n. 2, p. 205-11, 1987.

19. The Reportes of the Dietary Guidelines Advisory Committee on Dietary Guidelines for Americans, 2005. Disponível em: <http://www.health.gov/ dietaryguidelines/dga2005/>. Acesso em: 26 out. 2007.

20. SALAROLI, L. B. et al. Prevalence of metabolic syndrome in populationbased study, Vitoria, ES-Brazil. Arq Bras Endocrinol Metabol, v. 51, n. 7, p. 1143-52, 2007.

21. SPOSIT0, A. C. et al. IV Brazilian guideline for dyslipidemia and atherosclerosis prevention: department of atherosclerosis of Brazilian Society of Cardiology. Arq Bras Cardiol, v. 88, Suppl. 1, p. 2-19, 2007. 
Eliane Soler Parra; Vanessa Helena de Souza Zago; Natália Baratella Panzoldo; Fernanda Alexandre; Felipe Vendrame; Vitor Wilson de Moura Virginio; Isabela Calanca Vieira; Marcelo Scarpari Dutra Rodrigues; Angela de Souza Cassol; Fabio D’Alexandri; Vera Sylvia Castanho; Rui Nakamura; Jamal Baracat; Mirian Regina Gardin Danelon; Ronise Carla Sass Pozeti; Ana Cândida Coutinho Facin; Hilda Maria da Silva Honorio; Simone

de Cássia Dias Mesquita; Marcio Jorge da Silva; Marielza Crosgnac Feres Lot; Valéria Sutti Nunes; Camila Canteiro Leança; Edna Regina Nakandakare; Eder Carlos Rocha Quintão; Eliana Cotta de Faria

22. SUGIUCHI, H. et al. Direct measurement of high-density lipoprotein cholesterol in serum with polyethylene glycol-modified enzymes and sulfated alpha-cyclodextrin. Clin Chem, v. 41, n. 5, p. 717-23, 1995.

23. TEICH, V.; ARAUJO, D. V. Estimativa de custo da síndrome coronariana aguda no Brasil. Rev Bras Cardiol, v. 24, n. 2, p. 85-94, 2011.

24. TIAN, L. et al. Gender and age differences in the distribution of the HDL subclasses among the Chinese population. Eur J Lipid Sci Technol, v. 112, p. 502-10, 2010.
25. WEST, M. et al. Scavenger receptor class B type I protein as an independent predictor of high-density lipoprotein cholesterol levels in subjects with hyperalphalipoproteinemia.J Clin Endocrinol Metab, v. 94, n. 4, p. 1451-7, 2009 .

26. ZAG0, M. A. Clinical research in Brazil. Ciência \& Saúde Coletiva, v. 9, n. 2, p. 363-74, 2004

\section{MAIL ADDRESS}

Eliana Cotta de Faria

Rua Tessália Vieira, 126; Barão Geraldo - Campinas-SP, Brasil; CEP: 13084-971; Caixa postal: 6111; e-mail: cottadefaria@gmail.com. 